\title{
Andrea Bottalico*
}

\section{Automation Processes in the Port Industry and Union Strategies: The Case of Antwerp}

https://doi.org/10.1515/ngs-2022-0003

Received January 6, 2022; accepted January 17, 2022

\begin{abstract}
Automation represents a sensitive issue in the debate between social actors of the port-maritime industry. Automation produced a contraction of the number of dockworkers since the 1960s. However, the idea that technological innovation will produce the disappearance of work is not sustained by empirical evidence. For this reason, trade unions have been particularly watchful. Despite the discourses about robotization carried out by supply chain operators, the paradigm of the post-COVID logistics chain is still based upon the human labor cost. During the pandemic there has been a transformation in working conditions not in terms of replacing people with robots, but rather of the robotization of workers to obtain the maximum productive exploitation at the minimum wage allowed. The purpose of this article is to provide an analysis of labor relations and workers organizing in light of the automation processes in the European port of Antwerp. The article focuses on how working conditions and jobs are potentially impacted by automation in ports, and on how workers disruptive strategies are resisting to these dynamics. The following questions have been answered: How do trade unions and dockworkers respond to automation? What are the strategies implemented in the bargaining processes?
\end{abstract}

Keywords: port labor systems, maritime-logistics chain, automation, labor relations, unions, global supply chain

\section{Introduction}

The transport of goods is one of the crucial industries of the global economy. The extant health crisis determined by the spread of COVID-19 has increased the awareness of the interdependencies between economies and of the need for companies to reflect on the configuration of their business models. The 2021 blockage of the Suez Canal by a container ship has further highlighted the role of the maritime-logistics industry which, while playing a key role in sustaining

*Corresponding author: Andrea Bottalico, University of Naples “Federico II," Naples, Italy, E-mail: andrea.bottalico@unina.it. https://orcid.org/0000-0002-1916-473X 
economic globalization through the development of intermodality, has also experienced a paradigm shift. In contrast to the past when competition took place between shipping companies, today's market competition occurs along the entire global logistics chain connecting the origin to the destination of goods. As links of broader global supply chains and of global production networks, shipping companies seek to control the whole value chain to leverage economies of scale and obtain greater labor flexibility (Bottalico 2018).

The port industry has been strongly influenced by radical innovation initiatives in the last decades such as automation processes, affecting employment relations and work organization. Different strategies have been implemented by supply chain workers and trade unions to face these processes. Within this context ports have become the epicenters of labor mobilization against the combination of economic, structural, and organizational changes; and of choices concerning political economy, with dockworkers at the center of action. This article assumes a particular role for a better understanding of the innovation initiatives that have an impact on work organization and employment relations, focusing on the main forms of worker organizing. While several writings investigate specific case studies of innovation or investment patterns with a focus on technical advancements, few studies focus on understanding the interaction among innovation initiatives and worker actions, resistance, and organizing. This article therefore tries to fill this gap by answering the following research question: How do trade unions and dockworkers respond to automation, and what are the strategies implemented in the bargaining processes?

One of the common peculiarities of port labor is related to the uncertain dynamics of maritime traffic. This means that the lead firm of the maritime-logistics chain, the Dominus inside a port, is the shipping company. Typically, dockworkers work "on call." The demand for dock labor by a port employer is based on the average level of trade and, in moments of peak workloads, the use of temporary work, which represents the element of flexibility part that is required to handle goods. The temporary work, in turn, is often framed within a peculiar regulation in Europe, obtained by the workers after decades of conflicts and mobilizations. Given its irregularity, port labor is a traditional form of waterfront work related with militancy, casualism, and close-knit communities (Mah 2014). These characteristics allow us to underline the complex and conflictual nature of the port industry. Casual by definition, port labor has hence a long history of labor struggles and constantly fluctuating processes of casualization and de-casualization (Davies et al. 2000; Levinson 2006).

Port labor market regulation has been contested frequently around the world. Conflicts in ports have shaped the historical development of the port labor force, resulting in transnational solidarity mechanisms and high rates of unionization 
among workers. Technological innovations also radically transformed labor organization and power relations over time, as well as union strategies, occupational competencies, and the composition of the workforce itself (El-Sahli and Upward 2017).

Labor conflicts in ports remain the order of the day, despite port management's attempts to minimize them to avoid disruption in a key segment of the global economy that pays dearly for any blockage of operations. In the era of the logistics revolution, ports remain chokepoints (Alimahomed-Wilson and Ness 2018). The structural power of workers has fostered the achievement of high labor standards, continually under attack (Silver 2003). In port chokepoints, a strike can have disruptive effects that reverberate along global supply chains. In light of this bargaining power, the port workforce faces many challenges that tend to threaten their very existence, to erode its conditions and regulation, increasing precarity. However, the strategic position of the port workforce within the global supply chains alone might be not sufficient, in the long run, to counter these general trends.

Dockworkers usually handle global cargo, but at the same time they are locally situated and socially embedded. This is one of the reasons why ports are places of conflicting interests, providing a relevant field of study for observing how labor dynamics change in light of capitalist globalization. The study of port labor conflicts can tell us something more general about the impact of global production networks on local employment conditions.

Employment and industrial relation analyses have concentrated on unions' mobilization strategies and practices to seek and contain the dismantling of longestablished employment conditions (Alimahomed-Wilson and Ness 2018; FoxHodess 2017; Turnbull 2006, 2010). While under attack everywhere, port labor systems appear to have a diverse capacity to respond to challenges such as automation trends, as the outcome of power relationships, worker resistance, tactics and strategies of unions, but also in light of the historical heritage of each port.

This article answers the above-mentioned research questions by providing an analysis of the case of Antwerp (Belgium). Based on qualitative fieldwork carried out between 2016 and 2019, the article focuses on the resistance of dockworkers and their trade unions against automation trends in the logistics hub of Antwerp, among the most performative and efficient ports worldwide, integrated with a distinctive institutional context, a specific port regulation, a peculiar system of employment relations and work organization.

Section 2 of this article presents a review of the debate on automation processes in the port industry. Section 3 provides an empirical analysis of the case 
study. Finally, Section 4 summarizes the key arguments and discuss the findings, by stressing the need for further research in this direction.

\section{Automation Processes in the Port Industry}

Recent research in the maritime-logistics industry has mainly focused on the challenges brought about by globalization (Alimahomed-Wilson and Ness 2018; Turnbull 2006). Great emphasis has been paid to the new repertoire of coordinated strategies that unions have adopted to counteract globalization tendencies in the industry (Fox-Hodess 2017; Lillie 2006).

The reconfiguration of global supply chains, technological innovation as well as the affirmation of liberalization principles have all impacted the organization and composition of the workforce and employment relationships by triggering a wave of conflicts. In Europe, during the years of the "war on the waterfront" (Turnbull 2006, 310) the European Union's (EU) directives were aimed at liberalizing port services. Traditional bureaucratic forms of collective representation have successfully merged with international strategies of conflict hinging upon transnational networks, capable of creating greater coordination between the dockworkers of different European countries against EU directives. Scholars have pointed to the balance between local, national, and transnational dimensions of trade union action as the main challenge posed by international coordination and have sought to explain cases of success and failure. Turnbull observed a generalized loss of bargaining power by dockworkers. However workers' struggles against EU directives to protect the existing employment conditions suggest that the efforts of trade unions to rely on the force of logic" to persuade EU officials was successful only when it was supported by the "logic of force" of dockers in the workplace (Fox-Hodess 2017; Turnbull 2006, 7).

Through a comparison of international solidarity of the Portuguese, Greek, and English affiliates of the International Dockworkers' Council (IDC) at the European level, Fox-Hodess (2017) adds that successful internationalism occurred when political conditions and ideological traditions allowed for the construction of direct and concrete links between workers in different employment contexts. This work calls attention to the central role played by the local-to-local shop-floor coordination in transnational campaigns and by key local activists. Such international solidarity can however fail when national bureaucratic issues affect local level organizing. National and transnational union structures have themselves become a source of hindrance of grassroots initiatives when reproducing bureaucratic models of international coordination (Waterman 2001). 
The focus on the organization of labor agency in ports and on its mobilization in the context of globalization pressures has led to neglecting precisely those pressures and especially the scrutiny of the changing capitalistic structure in the maritime-logistics chain leading, inter alia, to changing power relationships. These reflect local organizational specificities as well as path dependent social and institutional regulatory dynamics rooted in time and space. Thus, while acknowledging that solid trade union organizations at the local level represent a crucial element for effective coordination at transnational level, the exploration of that local dimension remains atrophic. Power relationships in the port of Genoa (Italy), for example, are different from the greenfield port of Gioia Tauro (Italy) or Koper (Slovenia), or from the ancient Hanseatic ports of Rotterdam (Netherlands) and Hamburg (Germany).

History matters in these cases. The differences come mainly from the way in which labor is organized, on the strength of the unions at local level, on the workers composition, and in the sedimented history of a port city. Moreover, these differences rely on the port labor regulations still in place to protect working conditions from the market requirements, despite the attempts of the European Union to liberalize the port industry. Beyond common traits, European ports differ in the way in which labor is regulated and organized by trade unions, and not all of them are exactly like "chokepoints." Thus ports differ also in the way radical innovation initiatives such as automation processes are negotiated and faced by workers' struggles. The strategic position of the port workforce alone is not sufficient to counter these general trends that affect other economic and productive sectors.

A number of individual innovation initiatives have been documented in the port industry. Examples can be found in container terminal optimization (e.g. Kaveshgar and Huynh 2015), environmental management in seaports (Klopott 2013), ICT (Keceli 2011), hinterland chain planning, and maritime-logistics hub development (Yang, Liang, and Ding 2013).

Concerning the maritime and port sector, innovation is a strategy that promotes competitiveness (Jenssen 2003), especially with the impact of COVID-19 on the maritime-logistics chains. The notion of a "Smart Port," for example, identifies a port that uses automation and innovative technologies to improve its performance. As technological innovations develop, ports might become a "digital node" within the global supply chain (Port 2019).

The literature often focuses more on the assessment of investments (Zheng and Negenborn 2017) than on the evaluation of innovative processes and the impact on employment. Nevertheless, while all these studies focus on specific characteristics related to a particular innovation goal (or process), only few other scholars analyze the resistance of workers in these dynamics and the elements affecting labor. 
It should be underlined, however, that the future development of the port industry and the challenges of change driven by the advancement of new technical and operational models cannot ignore the aspect of port labor systems and employment relations. This, in turn, highlights the role of the trade unions and the workers' disruptive strategies capable of counteracting these processes along the global supply chains.

Work organization in ports has been strongly affected by radical innovation initiatives in recent decades, whereas automation processes have produced an unavoidable contraction of the number of dockworkers. Trade unions are particularly watchful and sensitive about the topics related to innovation initiatives and automation processes. Automation seems to be a strategic option for every port but is not the standard for an efficient terminal. It refers to the application of "automatic control" and the use of programmable logic controllers in machinery (PLC), such as Automated Stacking Cranes. It is further acknowledged by the unions that automation reduces human intervention but not necessarily employment, and that it is a very slow, gradual process.

At the moment, automation has not reduced operating expenses or increased productivity as much as expected. The impact of automation on labor is substantial in the conventional port sector which involves a workforce with a considerable share of field labor (Dynamar 2019). According to the European Transport Workers Federation (2017), the purpose of automation is to achieve higher throughput or productivity, lesser direct human labor costs and expenses. The risks of automation concern the reduction of operational flexibility, the reduction of financial flexibility (fixed costs), high initial costs, security, and vulnerability. In addition, some tasks cannot be automated, or only at high costs. The risk of operational control produces an additional automation paradox: the more efficient the automated system, the more crucial the human contribution of the operators. Humans are less involved, but their involvement becomes more critical.

In container terminal operations the potential impact on dockworkers depends on the terminal concept (greenfield/expansion/brownfield), increase of volume and terminal capacity in relevant ranges, current job structure and collective labor agreements, labor market, job content, and working conditions. However, the job and qualification structures are affected. Automation impacts labor by producing a shift from direct to indirect jobs and in terms of skills and job losses. It may result in changes to health risks and demands for flexibility which may increase (such as with more peaks, tight schedules, etc.). According to the trade unions, the impact on total employment in the next few decades is uncertain, while the impact on unskilled/lower skilled workers is expected to be high (Esser et al. 2019; European Transport Workers Federation 2017). 
According to a recent study by Dynamar (2019), employee training continues to be a source of competitive advantage for the terminal operators in Europe. Nevertheless, the current organization of port labor on conventional terminals is expected to be impacted by changing requirements of port worker's skills and competencies, which are focused on the need for multi-functionality, training, skills and career path, and need for lower labor costs, high productivity, and flexibility.

Analyzing the main differences in labor intensity and automation of container terminals of Antwerp and Rotterdam (where a fully automated terminal is running), Van Den Driessche, van der Lugt, and Streng (2019) discussed the port value added for container traffic, arguing that labor and capital intensity vary based on terminal history, absorptive capacity, and strategic priorities. The authors underlined, among the benefits of automated ports, the operational performance, increased safety and security, environmental sustainability, and operational expenses. Among the potential drawbacks of automation are the cost of implementation, the availability of skills and resources, and the labor cost. According to these authors, the relationships between automated terminals and increased labor costs may be affected by the power of trade unions, which are stronger in countries with expensive labor.

The prevailing logistics chain configuration has led to the intensification of the pace of work, the reduction of handling time, and the co-existence of peak workloads together with labor shortages and requests for greater flexibility. The automation of terminal processes has emerged as an option for increasing efficiency at the expense of labor. Moreover, in contrast to the past, dockworkers and their unions are now asked to negotiate their conditions not only with the terminal operating companies, but also with their customers, i.e. the shipping companies. The case study of Antwerp, as we shall see in the next section, precisely displays these structural tendencies, as well as the response of the organized labor.

\section{The Antwerp Case}

\subsection{Introduction}

The port of Antwerp is among the top European logistics hubs, located in the Rhine-Scheldt Delta, the largest port region in Europe in terms of volume. In Belgium, ports are currently regulated by the so-called Major Act (June 1972) which stipulates that only recognized dockworkers are entitled to work in the port area. ${ }^{1}$

1 Port workers must be recognized by the Joint Subcommittee of the port, after fulfilling a number of conditions such as be medically fit for port labor, knowledge of the Dutch language, etc. 
This means that all cargo handling activities, goods entering or leaving the port, and services related to these goods must be treated by registered port workers from the labor pool, with a few exceptions. According to the Major Act, port employers cannot hire dockworkers from the external labor market.

The port labor pool includes highly unionized workers who can be assigned according to various professional occupations. In light of the nature of labor contract with the port employers involved in handling different types of goods, Antwerp port workers can be further subdivided into permanent workers hired by one port employer and casual workers. The latter work on call and are hired by the different port employers on a daily basis through the hiring hall. There are also quasi-permanent dockworkers. They are typically hired daily, for a longer definite period, and always by the same port employer.

By looking at the composition of the workforce, in that way the president of VOKA Alfaport (the Chamber of Commerce of Antwerp) explains this "strange connection between casual and permanent labor," underlying the peculiar relationships between status and contract among the Belgian dockworkers (Interview n. 10, 25 October 2016):

In Antwerp there is a very strange connotation about casual labor. We tried to find out officially if Antwerp dockers are still casual workers. The majority of them still have a causal employment relationship, so they still are employed via the pool. A large majority of them are working 4 out of 5 days a week for the same terminal operating company, day in day out, year in year out. So officially, they still are casual workers, in practice they are working to [STET] the same company. There was very strong connection between groups of workers and some companies. In case of strikes or social conflicts, the Antwerp docker is extremely proud and finds it extremely important that he still is a casual worker. It has to do with symbolism. They want to keep their status, which is related somehow with symbolic liberty.

Symbolic or not, the Antwerp dockworker in principle is unionized and has no bosses (or, on the contrary, has many bosses). Regardless of the nature of their contracts, all the dockworkers have the possibility returning to the hiring hall (e.g. the fallback option) when demand is low. Terminal operators can return unneeded dockworkers to the hiring hall as well. Dockworkers confronted with a short or prolonged period of unemployment are provided with guaranteed payments mainly financed by the federal government via an unemployment benefit and partly by the employers via a special fund.

In 2016, the total number of recognized workers belonging to the labor pool in Antwerp was about 6,125. In 2021, the total number was about 6,663. Mainly due to containerization, requiring more technological inputs, the labor pool in Antwerp has decreased substantially since 1980. The logistics workforce involved in the port area increased slightly (from 1696 in 2006 to 1753 in 2015). In recent years, the 
number of tasks has stayed around the same level, namely between 1.16 and 1.19 million units, while the average number of tasks per dockworker increased from 188 in 2014 to 195 tasks in 2015, or an increase of 3.5\%, signaling an increase in labor productivity.

All port employers operating within the geographical borders of the port of Antwerp are obliged to employ the recognized workforce from the labor pool for all port activities. In addition, they are obliged to join the Centrale des Employeurs au port d'Anvers (CEPA). CEPA was set up in 1929, is in charge of managing personnel and salary payments for all the dockworkers recognized in the port of Antwerp, and is also engaged in collective bargaining with the trade unions. This institution also has responsibility for training the labor force using the training center for dockworkers, which offers obligatory professional training courses with the joint supervision of the port employers and the three trade unions: the main representative is the Socialist union Algemeen Belgisch Vakverbond - Belgische Transportarbeidersbond (ABVV-BTB), the Christian union Algemeen Christelijk Vakverbond - Transport \& Communicatie (ACV-Transcom), and the Liberal union Algemene Centrale der Liberale Vakbonden van Belgie (ACLVB).

Two main goals are therefore linked to CEPA since the beginning. First, to structure the labor force to be employed in the port through a list of registered workers entitled to accomplish port labor in the port area (via the mediation of the trade unions). Second, to set up and organize the central system of payment.

In Belgium, the bargaining system uses both a general collective bargaining agreement at the national industrial level and a collective bargaining agreement at sub-industry level. Moreover, employers and trade unions at the port level can bargain a specific agreement called "Codex." The definition of dock work is on the first page of the "Codex" - considered as the "Bible" of the dockworkers. The Codex of the port of Antwerp - written in Dutch - is only applicable in that port. In each port, the Codex set in detail the prevailing labor regulations applicable within the port. The port-specific Codex contains stipulations on wages and working conditions, mandatory compositions of the gangs, etc., and includes a clear description of the geographical area for which the regulation applies. The existence of labor regulation through a Codex implies that competition among terminal operators in the same port is based on service and productivity rather than labor costs. Changes and additions to a port's Codex are under the responsibility of the competent joint subcommittee in which representatives of both employers and trade unions negotiate. The joint subcommittee of the port of Antwerp is formed by CEPA, the trade unions and a representative of the federal ministry of labor. In the words of the director of CEPA Guy Vankrunkelsven (Interview n. 06, October 15, 2016), the joint committee is "an institution that controls if things are going in the right and same way within a sector, with the supervision of the government." In 
homage to a rooted tradition and path dependent institutions such as CEPA and the joint subcommittee, economic and social actors are therefore involved in negotiations that ensure a shared agreement which would safeguard, at least in principle, market efficiency, and social peace.

\subsection{Recent Trends}

Automation processes or innovation initiatives in the port of Antwerp should be framed within this general context. Moreover, three major events recently affected market conditions, power relationships, and working organization in the port of Antwerp.

First, in 2016 a port labor reform took place in Belgium after the infringement procedure sent by the European Union to the Belgian government, concerning the incompatibility of the port labor regulation with the principles of the European Treaty on freedom of establishment and freedom to provide services which is contained in Article 49 of the Treaty on the Functioning of the European Union (TFEU). Since 2014, a wave of strikes carried out by the dockworkers in Antwerp and Brussels led to a negotiation between Belgian government, trade unions, and European Union. These conflicts have fostered the process of building power and cohesion in the workforce. The forms of protection from external tensions to which port labor is continuously subjected were conceived as "restrictions" to the free market by the European institutions. After months of workers' struggles, a compromise was reached in 2016 when the Belgian government proposed a port labor reform to be implemented over the next few years. Among the main changes, port employers can in principle hire in the future dockworkers from the external labor market. Moreover, the composition of gangs and the training system have been attacked.

Second, the strategic terminals in the port of Antwerp have begun to be managed by global players and multinational companies. The global terminal operating company Port of Singapore Authority (PSA), for example, obtained a dominant position in the container business with the acquisition of Hesse NoordNatie (HNN) in 2002. Furthermore, DP World from Dubai took over P\&O ports (2005-6).

Third, a new container terminal is managed through a vertical integration between the shipping company MSC (Mediterranean Shipping Company) and the global terminal operating company PSA. Along this line, the most notable development in 2016 was the transfer of all MSC services to the Deurganckdock on the left bank of the river Scheldt (quay 1742). Operated by 41 gantry cranes and 200 straddle carriers along a quay of about $3.7 \mathrm{~km}, 2420.000 \mathrm{~m}^{2}$, and a total capacity of 
nine million TEUs, MPET (MSC PSA Europe Terminal) is the largest container terminal in Europe.

\subsection{Automation Processes and Union Strategies}

With the development on new terminals, port employers tried at first to introduce disruptive innovation initiatives such as automation processes. However, the new container terminal MPET in the port of Antwerp, built from scratch, has not been characterized by a radically different organizational model or innovative solutions in contrast to the other container terminals. After initial intentions geared towards automating operations, no fully automated systems have been implemented by the management. The economic operators chose to not exceed the existing level of semi-automation on their terminals. The main reason for this is that the workers and their trade unions promptly negotiated these decisions, threatening to disrupt operations and impose themselves through their bargaining power. The automation discourse was therefore used by the economic operators as a deterrent for the productivity of the dockworkers by using its proximity to the port of Rotterdam and its fully automated Maasvlakte II container terminal. Alex, a dockworker of the labor pool and union delegate of the Belgian Union of Transport Workers (ABVV-BTB), explains this point (Interview n. 14, 18 November 2016):

\footnotetext{
Automation does not get through because it is not flexible enough. In our operations, if you want to change a complete shift-loading plan, you can do that, and it happens. In an automated terminal, you can't change anything because [it] is too rigid. That is currently our strength here: you can change plans in one hour, and at the moment the amount of containers we handle here with one gang is still higher than the amount of an automated terminal like in Rotterdam, which is on our neck.
}

Automation processes which may affect work organization and employment conditions have been negotiated through the logic of force in the workplace. A cohesive and highly unionized labor pool defended its interests within a frame characterized by a mediated system of interests in which nobody could ever "prevail" over the others. However, it seems from Alex's words that the price to pay for not choosing to introduce automation processes was a demand for greater flexibility.

Before being involved in port operations, dockworkers are supposed to acquire a proper knowledge, training and experience concerning both the tools that they are going to handle and of the environmental conditions in which they operate. This also feeds career expectations and has a direct impact on dockworkers' productivity. Professional training is managed and organized by CEPA, involving 
trade unions and port employers which include newly arrived shipping companies and terminal operators. These dynamics are routinized over time and further legitimated by the composition of the port labor pool, strongly defended by trade unions.

From the viewpoint of the dockworkers, it seems therefore that operational flexibility is a key element for work organization in the port of Antwerp. There are apparently few incentives to automate labor processes, and in any case trade unions would not allow it. Port employers involved in container handling ended up sharing the idea that complete automation in the port of Antwerp contrasts with the path dependent and historical "organization of the improvisation" in the workplace which has been negotiated by the employers and unions as social partners in the bargaining processes. The "human factor" in the port of Antwerp therefore is more "flexible" in contrast to an automated terminal. This perspective may be further demonstrated by the above-mentioned 3.5\% increase in 2015 of the average number of tasks per dockworker.

A key aspect related to automation processes is the training system, strongly defended by trade unions, which are aware of the evolution of the job skills. Professional training provides necessary additional training needed to make sure that dockworkers maintain high levels of productivity. Port employers benefit from this professional upgrading provided by the training system, investing in training according to the principle that "you spend money to gain money" (by always looking at the costs).

Despite the ongoing transformation processes determined by technological innovations, in Antwerp the key strategy of the unions has been a powerful and intrusive unified presence that reiterates their structural workplace power. The labor union power in the bargaining process is not just a "factor affecting the level of automation” (Van Den Driessche, van der Lugt, and Streng 2019), but a beneficial factor affecting the overall port labor system, which translates into political power to ameliorate working conditions and to ensure high standards. Trade unions in Antwerp have tried in this way to defend the core of unionized workers of the labor pool in light of the changes envisaged by the automation processes in port terminals and the pressures of the port employers. As the union leader of the ABVV-BTB states (interview n.16, 14 January 2017):

Port employers wanted to automate the terminals or hire people with low skills, non-unionized, from outside the labor pool. But we have highly skilled dockers, we have a well-known training center for the safety of our workers. We have made sure during the negotiations that this possibility is difficult for employers to undertake.

Making life difficult for port employers: in the words of the union leader, trade unions in the port of Antwerp have undertaken a substantially mediated process of 
bargaining, trying to counterbalance the power of the port employers through their compact size and cohesive strength, strengthened following the wave of conflicts against EU directives. In an institutional architecture, hinged upon joint decisionmaking bodies and a single specific port regulation, trade unions have found a constructive way to negotiate both productivity, flexibility, and wage issues as well as labor conditions, training, and organizational aspects such as the introduction of radical innovations. The arrival of foreign capital has not managed to scrap such a dense and articulated bargaining power. Despite their greater strength when compared to local employers, global shipping companies and terminal operators have been not only expected to negotiate with trade unions but have ended up recognizing the workers' disruptive power as a sort of "beneficial" value (as if the conflict presupposed capitalist development). The high level of training and overall professionality, which require continuous investments, is supposed to increase productivity and ultimately employers' economic returns.

However, the specter of automation lurks in the port of Antwerp, and the results are not satisfactory. For instance, the management of the brand-new container terminal MPET tried to substitute the tallymen with the Automatic Character Recognition system (ACR). Marc, a foreman of the container terminal MPET and union delegate of the ACV-Transcom (Interview n. 21, 21 March 2017), explains that the unions in this case agreed to this decision (discussed in the Joint Subcommittee), but the dockers at workplace warned the unions and the company of the possible operational risks. Consequently, no tallymen were trained in the training center for dockworkers. Over time the management realized that this automated system did not work like they had hoped. When they decided to use again the tallymen for this task, there was shortage of these professional profiles, because training had stopped. As a kind of boomerang effect, the decision taken by the company and its failure has strengthened the union's position and legitimation with respect to the negotiation of the introduction of automation processes in the work organization.

Dockworkers of Antwerp are often cited for having high rates of productivity (Notteboom 2010). Besides the gang system and a peculiar "labor culture," a key incentive is linked also to the competition with the nearby port of Rotterdam - as already mentioned - where a fully automated terminal is running, as the dockworker Marc emphasizes:

We are all paid the same, there are no incentives. The incentive for me in doing things good and not the other way around is chauvinism. We are proud to be dockers. That's simple. You don't want to deliver bad work, nobody does, no docker in Antwerp want to produce something bad. Most dockers know that there is a port from here only $100 \mathrm{~km}$, Rotterdam it's on our neck, and they have automated terminals. We must be better than their robots. 
The pivotal role of trade unions has been crucial in the mediation between the cargo handling companies and the dockworkers. They defended the dockworkers with their daily problems, providing assistance when there were difficulties at workplace, in the hiring procedures, etc. The shop stewards are located in the workplace, assessing whether the Codex is respected, or whether some issues occur between the employers and the workers, and try to solve disagreements.

The bargaining power of trade unions is further explained by the general manager of Katoen Natie, the main logistics operator in the port involved in conventional cargo (Interview n. 13, 12 April 2017):

What employers try to avoid in the port of Antwerp is contaminating one company with two systems, whereby you have dockers and non-dockers. We try to avoid that, because the risk that the dockers will say that the other needs to be a docker as well is too high. In my company I will never put unionized dockers and non-dockers in the same group, because it's too easy to open attack for the unions. They can easily unionize the non-unionized workers.

By referring to the possibility to hire workers outside the pool system (the key change in the port reform implemented after the infringement procedure), the interviewee stresses the "contamination risk."

To sum up, automation processes are framed within a broader context of ongoing changes who affect power relationships in the port of Antwerp. Trade unions adopted a strategy aimed at counterbalancing with their structural workplace power the market pressures and the attacks of multinational companies. Professional training seems to be the main battleground in a far from finished struggle that is only apparently low intensity. Strongly involved in the daily life of the dockworkers, trade unions are facing cohesively, after a period of strikes capable of closing ranks in the workforce, multinational market players locally situated through the logic of force at workplace. The mere threat of disrupting operations at Europe's main logistics hub was enough to prevent process automation-oriented decisions.

\section{Conclusions}

In the case of Antwerp, the action of trade unions appears to have had an impact on automation initiatives and labor conditions. The port workers in Belgium - among the most productive in Europe - are protected against any distortions deriving from the casual nature of their work by a compensation fund created in 1946, financed exclusively by contributions from terminal operators, and jointly managed by the public and private sectors. Trade unions in the port of Antwerp have been strong and cohesive enough to force the employers to negotiate 
automation-related changes and decisions without having to disrupt the operations. In the case analyzed, unions have demanded and found a dialog in order to avert the choice undertaken in the neighboring port of Rotterdam, where a model based on a fully automated terminal has influenced the bargaining processes in Antwerp as well.

Trade unions have found a constructive ground to negotiate both productivity and wage issues as well as labor conditions, flexibility and therefore work organization, including training and the introduction of radical innovations. Through this kind of "cold war" strategy, they avoided the introduction of automation processes in the new port terminals.

The port industry, conceived as a segment of the maritime-logistics chain, has been strongly influenced by radical innovation initiatives in recent decades affecting labor organization and employment relations. Nevertheless, the impact of these ongoing processes on labor is mostly neglected in the scientific and sectorial literature. While several studies investigate specific innovation case studies or investment patterns, few studies focus on understanding the interaction among innovation initiatives and labor (El-Sahli and Upward 2017; Esser et al. 2019).

Despite the differing pace of change among European ports, port labor systems in Europe are undergoing a slow but gradual process of automation. These tendencies imply structural changes in terms of number of jobs, health issues, professional profiles, and knowledge issues, etc., and should be constantly monitored by workers and trade unions. In the Belgian case, trade unions negotiated innovation initiatives and automated systems in the bargaining processes, adopting a strategy aimed at counterbalancing the changed power relationships with the threat of disrupting the port operations. The structural power of workers has fostered the achievement of high labor standards which are continually under attack (Silver 2003). In port chokepoints, a strike can have disruptive effects that reverberate along global supply chains. In light of this bargaining power, the port workforce faces many challenges that tend to threaten their very existence, erode conditions and regulations, and increase precarity and flexibility. However, the strategic position of the port workforce alone is not sufficient, in the long run, to counter these general trends that affect other economic and productive sectors.

In recent decades, innovation initiatives and automation processes produced an unavoidable contraction of the number of dockworkers in the port sector. Port labor systems are confronted with specific labor challenges not commonly found in many other industries. Despite the discourses about imminent and inexorable robotization carried out by supply chain operators and their gurus, we rather see a transformation in working conditions not in terms of replacing people with robots as some analysts wish, but rather of robotization of workers to obtain the maximum productive exploitation at the minimum wage allowed. 
It should be underlined that these dynamics have been detected before the pandemic. There is room for further empirical studies in the various chokepoints and across the global supply chains able to explore the variety of responses implemented by the workers against their post-COVID condition. The impact of automation processes on labor raise questions about the workers ability to organize across the different segments of global supply chains. The process of robotization of the port cycles, for example, may reduce the contribution of human labor at workplace, but at the same time implies the contribution of software developers. Different supply chain workers with different skills and bargaining power are emerging in the digital transition era. In light of the robotization processes and market integration, rather than excluding labor due to an increase in automation, the most acute risk in the future concerns the potential trivialization of human action and its marginalization. Only the coordinated and transversal mobilization of workers can counter these dynamics.

\section{References}

Alimahomed-Wilson, J., and I. Ness, eds. 2018. Choke Points. Logistics Workers Disrupting the Global Supply Chain. London: Pluto Press.

Bottalico, A. 2018. "Across the Chain: Labor and Conflicts in the European Maritime Logistics Sector." In Choke Points. Logistics Workers Disrupting the Global Supply Chain, edited by J. Alimahomed-Wilson, and I. Ness. London: Pluto Press.

Davies, S., C. J. Davis, D. De Vries, L. H. van Voss, L. Hesselink, and K. Weinhauer. 2000. Dockworkers. International Explorations in Comparative Labour History, 1790-1970, Vol. 1. London: Routledge.

Dynamar, B. V. 2019. "The Changing Face of Ports: The Socio-Economic Impact of Market-Based \& Technological Developments on EU Ports." Unpublished final report.

El-Sahli, Z., and R. Upward. 2017. "Off the Waterfront: The Long-Run Impact of Technological Change on Dockworkers." British Journal of Industrial Relations 55 (2): 225-73.

Esser, A., C. Sys, T. Vanelslander, and A. Verhetsel. 2019. "The Labor Market for the Port of the Future. A Case Study for the Port of Antwerp." Case Studies on Transport Policy 8 (2): 349-60. European Transport Workers' Federation (ETF). 2017. "Shaping the Future of Dockwork." In ETF Dockers' Section Automation Seminar for Members. Antwerp, 25-28 June.

Fox-Hodess, K. 2017. "(Re-)Locating the Local and National in the Global: Multi-Scalar Political Alignment in Transnational European Dockworker Union Campaigns." British Journal of Industrial Relations 55: 626-47.

Jenssen, J. 2003. "Innovation, Capabilities and Competitive Advantage in Norwegian Shipping." Maritime Policy \& Management 30: 93-106.

Kaveshgar, N., and N. Huynh. 2015. "A Genetic Algorithm Heuristic for Solving the Quay Crane Scheduling Problem with Time Windows.” Maritime Economics \& Logistics 17 (4): 515-37.

Keceli, Y. 2011. "A Proposed Innovation Strategy for Turkish Port Administration Policy via Information Technology." Maritime Policy \& Management 38 (2): 151-67. 
Klopott, M. 2013. "Restructuring of Environmental Management in Baltic Ports: Case of Poland.” Maritime Policy \& Management 40 (5): 439-50.

Levinson, M. 2006. The Box. How the Shipping Container Made the World Smaller and the World Economy Bigger. Princeton: Princeton University Press.

Lillie, N. 2006. A Global Union for Global Workers: Collective Bargaining and Regulatory Politics in Maritime Shipping. New York: Taylor \& Francis.

Mah, A. 2014. Port Cities and Global Legacies. Urban Identity, Waterfront Work, and Radicalism. London: Palgrave Macmillan.

Notteboom, T. 2010. "Dynamics in Port Competition in Europe: Implications for North Italian Ports." Unpublished workshop paper.

Port Technology. 2019. “What is a Smart Port?” https://www. porttechnology.org/news/what-is-asmart-port/.

Silver, B. 2003. Forces of Labour. Workers' Movements and Globalization since 1870. Cambridge: Cambridge University Press.

Turnbull, P. 2006. "The War on Europe's Waterfront - Repertoires of Power in the Port Transport Industry." British Journal of Industrial Relations 44 (2): 305-26.

Turnbull, P. 2010. "From Social Conflict to Social Dialogue: Counter-Mobilization on the European Waterfront." European Journal of Industrial Relations 16 (4): 333-49.

Van Den Driessche, E., L. van der Lugt, and M. Streng. 2019. “Analysing Sustained Differences in Labor Intensity and Automation on Container Terminals of Two Major Port Hubs in the Hamburg-Le Havre Range." Unpublished conference paper.

Waterman, P. 2001. "Trade Union Internationalism in the Age of Seattle." Antipode 33 (3): 312-36.

Yang, W.-S., G.-S. Liang, and J.-F. Ding. 2013. "Identifying Solutions for Adding Service Value to International Port Logistics Centers in Taiwan.” Maritime Economics \& Logistics 15 (4): 395-415.

Zheng, S., and R. R. Negenborn. 2017. "Terminal Investment Timing Decisions in a Competitive Setting with Uncertainty Using a Real Option Approach.” Maritime Policy \& Management 44 (3): 392-411. 